\section{PNAG: broadening infection protection}

\section{by Michael J. Haas, Senior Writer}

A multi-institutional team has added more than 20 pathogens to the list of known bacteria that express poly- $N$-acetylglucosamine, a bacterial capsule polysaccharide that provides a potentially broad-spectrum target for vaccination. ${ }^{1}$ The findings open up new indications for Alopexx Vaccine LLC and Alopexx Pharmaceuticals LLC, which are already developing a vaccine and an antibody for passive immunization, respectively.

Over the past two decades, studies by multiple groups have identified poly- $N$-acetylglucosamine (PNAG), a polysaccharide encoded by a conserved four-gene locus, as a component of the surface capsule in at least seven species of bacteria. ${ }^{2-7}$

PNAG is one of many polysaccharides and other carbohydrate polymers found on the outer surface of bacteria that help prevent host macrophages and other cells from engulfing the pathogens.

Anti-PNAG antibodies have been found in circulation in humans and other animals, but these naturally occurring antibodies do not effectively kill PNAG-expressing bacteria or provide adequate immune protection against them, casting doubts on their prophylactic potential. ${ }^{8-10}$

Between 2005 and 2007, teams led by Gerald Pier showed that a

Table 1. Adding pathogens to the PNAG list. A study in Proceedings of the National Academy of Sciences ${ }^{1}$ has added 24 more species of Gram-positive bacteria, Gram-negative bacteria, fungi, yeast and parasites to the existing list of pathogens that express the surface antigen poly-N-acetylglucosamine (PNAG). There now are about 40 known species of pathogens that express the molecule.

\begin{tabular}{|c|c|c|c|c|}
\hline \multirow[b]{2}{*}{ Pathogen species ${ }^{A}$} & \multirow[b]{2}{*}{ Pathogen type } & \multirow[b]{2}{*}{ Type of infection or disease ${ }^{B}$} & \multicolumn{2}{|c|}{ Effect of anti-PNAG antibody ${ }^{c}$} \\
\hline & & & in vitro & in vivo \\
\hline Bacillus subtilis & Gram-positive bacteria & Commensal; food poisoning & Pathogen death & Unknown \\
\hline Campylobacter jejuni & Gram-negative bacteria & Gastroenteritis & Unknown & Unknown \\
\hline Citrobacter rodentium & Gram-negative bacteria & Veterinary (only in mice) & Unknown & Unknown \\
\hline Clostridium difficile & Gram-positive bacteria & Nosocomial infections & Unknown & Unknown \\
\hline Enterococcus faecalis & Gram-positive bacteria & Nosocomial infections & Pathogen death & Unknown \\
\hline Haemophilus ducreyi & Gram-negative bacteria & Chancroid (genital ulcers) & Unknown & Unknown \\
\hline H. influenzae & Gram-negative bacteria & Bacteremia, pneumonia, other infections & Unknown & Unknown \\
\hline Helicobacter pylori & Gram-negative bacteria & Gastritis; gastric ulcers & Unknown & Unknown \\
\hline Listeria monocytogenes & Gram-positive bacteria & Listeriosis & Unknown & Pathogen death \\
\hline Mycobacterium smegmatis & Gram-positive bacteria & None known & Unknown & Unknown \\
\hline M. tuberculosis & Gram-positive bacteria & Tuberculosis & Unknown & Unknown \\
\hline Neisseria meningitidis & Gram-negative bacteria & Meningitis & Pathogen death & Pathogen death \\
\hline N. gonorrheae & Gram-negative bacteria & Gonorrhea & Pathogen death & Unknown \\
\hline $\begin{array}{l}\text { Salmonella enterica serovars Typhi } \\
\text { and Typhimurium }\end{array}$ & Gram-negative bacteria & Gastrointestinal infections & Unknown & Unknown \\
\hline Streptococcus dysgalactiae & Gram-positive bacteria & Veterinary & Unknown & Unknown \\
\hline S. pneumoniae & Gram-positive bacteria & Pneumonia, otitis media and other infections & Pathogen death & Pathogen death \\
\hline S. pyogenes & Gram-positive bacteria & Group A streptococcal infections & Pathogen death & Pathogen death \\
\hline Candida albicans & Yeast & $\begin{array}{l}\text { Nosocomial, eye, urinary tract and other } \\
\text { infections }\end{array}$ & Pathogen death & Pathogen death \\
\hline Aspergillus flavus & Fungus & Aspergillosis & Unknown & Unknown \\
\hline Fusarium solani & Fungus & Corneal infection & Unknown & Unknown \\
\hline Cryptococcus neoformans & Fungus & Respiratory & Unknown & Unknown \\
\hline Plasmodium berghei & Parasite & Malaria (in animal models) & Unknown & Pathogen death \\
\hline P. falciparum & Parasite & Malaria & Unknown & Unknown \\
\hline Trichomonas vaginalis & Parasite & Vaginitis and urogenital infections & Unknown & Unknown \\
\hline
\end{tabular}

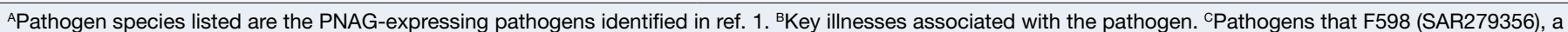

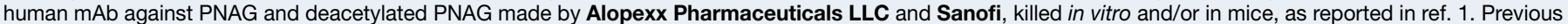

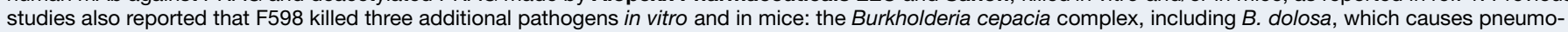
nia in patients with cystic fibrosis (CF): ${ }^{10}$ Escherichia coli ${ }^{11}$ and S. aureus, ${ }^{13}$ including methicillin-resistant strains (MRSA). 
deacetylated form of PNAG (dPNAG) elicited bacteria-killing antibodies in mice. ${ }^{6,11}$ His teams also developed a human $\mathrm{mAb}$-dubbed F598-that bound to both dPNAG and PNAG and killed bacteria. ${ }^{12}$

Pier is professor of medicine in microbiology and immunology at

"Our new study extends the list of PNAG-expressing organisms to most major human pathogens, including 9 of the top 10 causes of nosocomial infections."

- Gerald Pier,

Harvard Medical School
Harvard Medical School and a microbiologist in the department of medicine at Brigham and Women's Hospital.

In the current study, Pier's team investigated whether PNAG was expressed on bacteria and other pathogens in which the four-gene PNAG-producing locus has not yet been identified.

The group used F598 conjugated to a fluorescent agent to detect PNAG on the surfaces of pathogens and found the molecule in 24 pathogens not previously known to express it. Among the new pathogens were diseasecausing bacteria such as Streptococcus pneumoniae, Clostridium difficile and Mycobacterium tuberculosis, as well as the yeast Candida albicans and the parasite Plasmodium falciparum (see Table 1, "Adding pathogens to the PNAG list").

In human cell-based bactericidal assays, F598 increased killing of C. albicans, Neisseria meningitidis, S. pneumoniae and other pathogens compared with an inactive control antibody.

Lastly, the team tested the protective effect of the $\mathrm{mAb}$ in mice challenged with selected pathogens. In mice exposed to C. albicans, N. meningitidis, S. pneumoniae, S. pyogenes or P. burghei, pretreatment with the $\mathrm{mAb}$ led to decreased symptoms of eye infection, meningitis, lung infection, skin infection or cerebral malaria, respectively, compared with pretreatment with a control antibody or control serum.

"Our new study extends the list of PNAG-expressing organisms to most major human pathogens, including 9 of the top 10 causes of nosocomial infections" as reported by the Centers for Disease Control and Prevention (CDC), Pier told SciBX (see Table 2, "Nine out of ten for PNAG"). "This implies that a PNAG vaccine or passive immunotherapy with the anti-PNAG antibody could target a huge range of organisms with just one inoculation or treatment."
Pier noted that Pseudomonas aeruginosa is the only bacterium on the CDC's top 10 list that does not express PNAG.

Pier's team included researchers from Boston University School of Medicine, Dana-Farber Cancer Institute, Harvard School of Public Health, University of Massachusetts Medical School, The Ohio State University College of Medicine, The Research Institute at Nationwide Children's Hospital, Walter Reed Army Institute of Research, N.D. Zelinsky Institute of Organic Chemistry and Sanofi, which contributed some of the bacteria studied and tested F598 in the animals challenged with $S$. pneumoniae.

Data were reported in Proceedings of the National Academy of Sciences.

"The new study underscores that we have something unusual and even unique in our PNAG vaccine," said Daniel Vlock. "First, we have a target that is expressed incredibly broadly in pathogens. Second, we can produce the vaccine via chemical synthesis, which is certainly cleaner than recombinant methods, and we hope it will be simpler and cheaper as well."

In 2006, Pier and Vlock cofounded Alopexx Pharmaceuticals to develop F598 as a passive immunotherapy to protect against bacterial infections. Four years later, the duo cofounded Alopexx Vaccine, which has the dPNAG-based vaccine AV0318 in preclinical development to prevent bacterial infections in humans and production animals.

Vlock is CEO of both companies, which are part of the group Alopexx Enterprises LLC, which provides investment, managerial and development capabilities to its multiple subsidiaries.

In 4Q13, Alopexx Vaccine plans to begin testing AV0318 in cows to prevent mastitis caused by $S$. aureus and Escherichia coli and in pigs to prevent a severe form of pneumonia caused by Actinobacillus pleuropneumoniae, Vlock said.

"The immunogenicity and any toxicity we see in these animals will have an impact on what we can do in humans," he added.

Alopexx Vaccine expects to begin a Phase I trial of AV0318 in humans next year. Vlock declined to disclose the target populations or indications.

Meanwhile, Pier's team is testing F598 in vitro and in animals challenged with E. coli K1, Group B Streptococcus and other pathogens that cause neonatal infections in humans.

Table 2. Nine out of ten for PNAG. Multiple studies have determined that the surface antigen poly- $N$-acetylglucosamine (PNAG) is expressed on all but one of the pathogens responsible for the 10 most frequent nosocomial infections as reported to the Centers for Disease Control and Prevention (CDC) for 2006-2007. ${ }^{14}$ These 10 pathogens accounted for $87 \%$ of reported nosocomial infections in the U.S., including central lineassociated bloodstream infections, catheter-associated urinary tract infections, ventilator-associated pneumonia and surgical-site infections. Source: Refs. 1,10,13,15; Alopexx Vaccine LLC

\begin{tabular}{|c|c|c|c|}
\hline Pathogen & Type & PNAG expression ${ }^{A}$ & $\%$ of all nosocomial infections \\
\hline Staphylococcus epidermidis and other coagulase-negative staphylococci & Bacteria & Yes & 15 \\
\hline S. aureus & Bacteria & Yes $^{13}$ & 15 \\
\hline Enterococcus species, including E. faecalis & Bacteria & Yes $(\text { E. faecalis })^{1}$ & 12 \\
\hline Candida albicans & Yeast & Yes $^{1}$ & 11 \\
\hline Escherichia coli & Bacteria & Yes & 10 \\
\hline Pseudomonas aeruginosa & Bacteria & $\mathrm{No}^{1}$ & 8 \\
\hline Klebsiella pneumoniae & Bacteria & Yes & 6 \\
\hline Enterobacter species, including E. cloacae & Bacteria & Yes $(\text { E. cloacae })^{10}$ & 5 \\
\hline Acinetobacter baumannii & Bacteria & Yes $^{15}$ & 3 \\
\hline К. oxytoca & Bacteria & Yes & 2 \\
\hline
\end{tabular}

Andicates whether the pathogen expresses PNAG on its surface, as reported by the source cited. 


\section{ANALYSIS}

Pier said Brigham and Women's Hospital and Beth Israel Deaconess Medical Center hold a portfolio of patents covering the PNAG technology.

The antibody-related IP from that portfolio is licensed to Alopexx Pharmaceuticals, while the vaccine-related IP is licensed to Alopexx Vaccine, Vlock said.

In 2010, Sanofi exercised an option from Alopexx Pharmaceuticals to in-license F598 (SAR279356), which the pharma now has in Phase II testing to prevent bacterial infections.

Last December, Sanofi terminated a Phase II trial of SAR279356 for patients on mechanical ventilation in intensive care units because of difficulties with patient recruitment.

Sanofi declined to discuss the antibody's status or how Pier's new study might affect its development plans.

Haas, M.J. SciBX 6(23); doi:10.1038/scibx.2013.566

Published online June 13, 2013

\section{REFERENCES}

1. Cywes-Bentley, C. et al. Proc. Natl. Acad. Sci. USA; published online May 28, 2013; doi: 10.1073/pnas.1303573110

Contact: Gerald B. Pier, Harvard Medical School and Brigham and Women's Hospital, Boston, Mass. e-mail: gpier@rics.bwh.harvard.edu

2. Mack, D. et al. J. Bacteriol. 178, 175-183 (1996)

3. Lillard, J.W. Jr. et al. Gene 193, 13-21 (1997)

4. Kaplan, J.B. et al. J. Bacteriol. 186, 8213-8220 (2004)

5. Wang, X. et al. J. Bacteriol. 186, 2724-2734 (2004)
6. Maira-Litrán, T. et al. Infect. Immun. 73, 6752-6762 (2005)

7. Izano, E.A. et al. Microb. Pathog. 43, 1-9 (2007)

8. Skurnik, D. et al. J. Clin. Invest. 120, 3220-3233 (2010)

9. Gening, M.L. et al. Infect Immun. 78, 764-772 (2010)

10. Skurnik, D. et al. J. Infect. Dis. 205, 1709-1718 (2012)

11. Cerca, N. et al. Infect. Immun. 75, 3406-3413 (2007)

12. Kelly-Quintos, C. et al. Infect Immun. 74, 2742-2750 (2006)

13. Maira-Litrán, T. et al. Infect. Immun. 70, 4433-4440 (2002)

14. Hidron, A.I. et al. Infect. Control Hosp. Epidemiol. 29, 996-1011 (2008)

15. Choi, A.H. et al. J. Bacteriol. 191, 5953-5963 (2009)

\section{COMPANIES AND INSTITUTIONS MENTIONED}

Alopexx Enterprises LLC, Concord, Mass.

Alopexx Pharmaceuticals LLC, Concord, Mass.

Alopexx Vaccine LLC, Concord, Mass.

Beth Israel Deaconess Medical Center, Boston, Mass.

Boston University School of Medicine, Boston, Mass.

Centers for Disease Control and Prevention, Atlanta, Ga.

Brigham and Women's Hospital, Boston, Mass.

Dana-Farber Cancer Institute, Boston, Mass.

Harvard Medical School, Boston, Mass.

Harvard School of Public Health, Boston, Mass.

N.D. Zelinsky Institute of Organic Chemistry, Moscow, Russia The Ohio State University College of Medicine, Columbus, Ohio The Research Institute at Nationwide Children's Hospital, Columbus, Ohio Sanofi (Euronext:SAN; NYSE:SNY), Paris, France University of Massachusetts Medical School, Worcester, Mass. Walter Reed Army Institute of Research, Silver Spring, Md. 